\title{
CONTRIBUTIONS TO THE KNOWLEDGE ON LIVERWORTS OF SAKHALIN ISLAND (WEST PACIFIC)
}

\section{МАТЕРИАЛЫ К ПОЗНАНИЮ ПЕЧЕНОЧНИКОВ ОСТРОВА САХАЛИН (ЗАПАДНАЯ ПАЦИФИКА)}

\author{
V.A. BAKALIN ${ }^{1}$, V.YA. CHERDANTSEVA ${ }^{1}$, K.V. GOROBETS ${ }^{2} \&$ J. HARPEL $^{3}$ \\ В.А. БАКАЛИН ${ }^{1}$, В.Я. ЧЕРДАНЦЕВА ${ }^{1}$, К.В. ГОРОБЕЦ ${ }^{2}$, ДЖ. ХАРПЕЛЬ ${ }^{3}$
}

Abstract

There are data on the distribution and ecology of 72 species of liverworts of Sakhalin Island. Thirty four species of liverworts have been reported for the first time from the territory of Sakhalin. Among those three species (Isopaches bicrenatus, Nardia assamica, Orthocaulis binsteadii) are new to the south of the Russian Far East, one (Crossocalyx hellerianus) is new for East Asia, and one (Mylia nuda) is new to Russia. This is the first data on liverworts from the northern part of the island.

Резюме

Приводятся данные по распространению и экологии 72 видов печеночников острова Сахалин. 34 вида печеночников впервые отмечаются для территории Сахалина. Среди них, три вида (Isopaches bicrenatus, Nardia assamica, Orthocaulis binsteadii) являются новыми для юга российского Дальнего Востока, один Crossocalyx hellerianus - новый для Восточной Азии и еще один (Mylia nuda) - новый для России. Собраны первые данные о печеночниках северной части острова.

\section{INTRODUCTION}

Liverworts of Sakhalin Island have not been studied adequately and data is patchy. The major information on liverworts of the island is in Japanese papers and covers the southern part. Besides, there were no data on hepatics from northern $\mathrm{Sa}-$ khalin. That was the reason that initiated our research on the island.

In 2001, 2004 and 2005 the authors of the paper collected liverworts in various parts of the Sakhalin Island. In addition, some negligible collections of 2000 vouchers preserved in herbaria (VLA) have been studied as well. The results of the identifications of these collections have formed the basis of this paper. Hopefully, this paper opens a series of publications on bryophytes of the islands of the Russian Far East.

\section{STUDY AREA}

Sakhalin Island is located close by the eastern coast of the Asian continent and is stretched from the north to the south for $948 \mathrm{~km}$ (from $54^{\circ} 25^{\prime} \mathrm{N}$, Elizabeth Cape, down to $45^{\circ} 54^{\prime}$ N, Krilion Cape). It is separated from the mainland by the Tartar Strait, which is only $7.5 \mathrm{~km}$ wide in its most narrow neck (Nevelskoy Strait), and the La Perouse Strait (40 km wide) divides it from Japan (Hokkaido Island). Maximum width of the island reaches almost $160 \mathrm{~km}$ (at the latitude of Lesogorsk), and in its most narrow necks - the Poyasok Isthmus and the isthmus of the Schmidt Peninsula - is just 26 and $6 \mathrm{~km}$ respectively. In the north and the east the island is washed by the cold waters of the Sea of Okotsk, and in the west and south-west by the warmer Sea of Japan (Bogatov, 2004).

\footnotetext{
1 - Laboratory of Lower Plants, Institute of Biology and Soil Sciences FEB RAS, Stoletiya Vladivostoka av., 159, Vladivostok 690022 Russia - Лаборатория низших растений, Биолого-почвенный институт ДВО РАН, пр. Столетия Владивостока, 159, Владивосток, 690022, e-mail: v_bak@list.ru \& cryptogamy@ibss.dvo.ru

2 - Laboratory of Chemotaxonomy, Pacific Institute of Bioorganic Chemistry FEB RAS, Stoletiya av., 159, Vladivostok 690022 Russia - Лаборатория хемотаксономии, Тихоокеанский институт биоорганической химии ДВО РАН, пр. Столетия Владивостока, 159, Владивосток, 690022, e-mail: kgorobets@mail.ru

3 - Department of Botany, University of British Columbia, Vancouver, B.C. V6T 1W5, Canada, e-mail: wjharpel@earthlink.net
} 
Having emerged above the water as a result of orogenic processes at the end of the Cretaceous and the beginning of the Paleocene, Sakhalin Island connected and separated again from the mainland several times in the course of its geological development (Pletnev, 2004).

There are lots of mountains on the island. The mountains are low, of medium height, and generally run longitudinally. The major part of the island (to the north of the Poyasok Isthmus) in the west is occupied by the West Sakhalin Mountains. In the eastern part of the island there are the East Sakhalin Mountains with Lopatin Mountain (1609 m alt.) being the highest peak of Sakhalin. To the south of the Poyasok, the Susunaisky and Tonino-Anivsky Ridges are almost parallel. The plains form about $25 \%$ of the island's territory. The largest of those (the North Sakhalin Plain) is located on the northern end of the island. Two largest orographic formations: the West Sakhalin and East Sakhalin Mountains are divided by the Tym-Poronayskaya Valley.

The climate of Sakhalin is moderate and monsoon. The mean annual temperature in Sakhalin is lower than at the same latitude on the mainland. In the southern part it ranges from +3.0 to + $4.5^{\circ} \mathrm{C}$, in the north - from -2.0 to $-2.7^{\circ} \mathrm{C}$. It is worth noticing, that the January mean temperature ranges more than $15^{\circ} \mathrm{C}$ from the north to the south on the island, while the August temperature change is $5^{\circ} \mathrm{C}$ (Bogatov, 2004). By the coasts of the non-freezing Sea of Japan the winter is milder than on the coast of the Sea of Okhotsk which is covered with drift ice for a long time. And on the western coast the thermal distinctions between the north and the south are sharply pronounced. It is associated with relative «continentalization» of the territories facing the Asian continent. The coldest month on Sakhalin is January, and the warmest one is August.

As the distance from the shore increases inland the climate loses its oceanic character (most evident on the coast), and is distinguished by colder winters and warmer summers with a greater number of sunny days. The amount of precipitation increases from the north to the south. Mean annual precipitation varies from $400 \mathrm{~mm}$ in the north to $1000 \mathrm{~mm}$ in the south and it even reaches up to $1200 \mathrm{~mm}$ on the mountain slopes of eastern exposure (Alexandrova, 1982). It first snows from the middle of October, with stable snow cover formed in the central areas by the second half of November and by the end of December at the seaside. The mean snow depth is $50-70 \mathrm{~cm}$, and the maximum can reach $1-1.5 \mathrm{~m}$. The air moisture is high, in summer it is $80-85 \%$, in winter $70-75 \%$ humidity. Specific features of Sakhalin's climate are: 1) the precipitation maximum taking place to the end of summer - the beginning of fall (with their prevalence during the summer season), 2) hard wind climate, and 3 ) high relative air moisture. At the end of summer and the beginning of fall, typhoons descend on the island. These are tropical cyclones accompanied by abundant precipitation and storm winds (Atlas..., 1994).

The mountainous relief of Sakhalin and abundant precipitation create favorable conditions for a great number of rivers and streams, which are mostly shallow. There are more than 60,000 of them in total. The largest rivers are Tym $(280 \mathrm{~km})$ and Poronay $(250 \mathrm{~km})$. There are lots of lake-lagoons along the eastern shore and they are connected with the sea by small channel (Bogatov, 2004).

Sakhalin Island is located within the taiga vegetation zone. About two-thirds of the island is covered by forest with species composition varying greatly from north to south. The northern third of the island is mostly covered by larch forests (Larix gmelinii (Rupr.) Rupr. s.1.). Poorly forested oligotrophic bogs alternating with larch mires are widely distributed throughout the area. On well-drained sites with rich soils, spruce-fir forests (Abies sachalinensis Fr. Schmidt. and Picea ajanensis (Lindl. et Gord.) Fisch) play a secondary role in the plant cover and occupy small areas among the larch forests. Dry "tundra" covered with lichens, stunted birch, alder, pine and sweetbrier rose (Betula spp., Alnus spp, Pinus pumila (Pall.) Regel, and Rosa spp.) occurs along the northern sandy coastal areas. Meadows composed of reed-grass and sedge's are limited in distribution and occur inland from the coastal areas.

The mountains in the central portion of the island are dominated by spruce-fir forests in the lower elevations and by Japanese stone pine (Pinus pumila (Pall.) Regel) and Erman's birch (Betula ermani Cham.) in the higher elevations. The central part of the island is occupied by the Tym and Poronai lowlands and extensive agricultural development. These riparian areas are covered by deciduous forests of willows (Salix spp.), alder (Alnus hirsuta 
(Spash) Turcz.), birch (Betula platyphylla Sukacz., and poplar (Populus maximoviczii Henry, elm (Ulmus spp., and ash (Fraxinus spp.). Within the flood plains the herbaceous plants grow to gigantic heights with some reaching $3-4$ meters tall. The dominant herbaceous plants include: Petasites japonicus F. Schmidt., Polygonum sachalinense F. Schmidt., Angelica ursina (Rupr.) Maxim., Senecio palmatus Pall., Cacalia hastata L., Filipendula kamtschatica (Pall.) Maxim., reed grass, and ferns. The older flood plains are covered with mixed forests. Oligotriphic bogs are found within the Poronayskaya Lowland.

On the southern end of the island the forests are composed mostly of Picea ajanensis (Lindl. et Gord.) Fish ex Carr. and Abies sachalinensis Fr. Schmidt, with isolated occurrences of Picea glehni (Fr. Schmidt) Mast. reaching the northern edge of its range. In the lower elevations the forest floor is dominated by ferns and mosses although a pure moss cover rarely develops. At higher altitudes the predominant ground cover is composed of shrubs with Vaccinium ovalifolium Smith. Above 300-500 m altitude and south of $48^{\circ}$ latitude, along the south-western coast, thick birch (Betula ermanii Cham.) forests with a dense understory of bamboo (Sasa kurilensis (Rupr.) Makino) occur above the belt of dark coniferous forests. Sometimes the bamboo penetrates under the canopy of the dark coniferous forest. In the southern parts of the island the distribution of larch forests is limited by lowland water-logged areas. Japanese stone pine, (Pinus pumila (Pall.) Regel) forms thickets above the birch forests and often reaches down and forms a peculiar altitude inversion. Although according to Lopatin (1960) there is no alpine zone on Sakhalin Island, there are spots of alpine wastelands and small stony tundra's among the thickets of Japanese stone pine that resulted from fires and ground cover degradation due to erosion processes. At the extreme south-western end of the island on the Krilion Peninsula, some deciduous tree species form part of the fir community, they are: Phellodendron sachalinense (Fr. Schmid) Sarg., Kalopanax septemlobum (Thunb.) Koidz., Acer mayrii Schwer., etc. Large areas along the slopes of the seashore are covered with light forests of deciduous trees composed of Quercus crispula Blume, Acer mayri Schwer., and Kalopanax septemlobum (Thunb.)
Koidz. On marine terraces Japanese yew (Taxus cuspidata Siebold. et Zucc. ex. Endl.) appears in the spruce-fir forests. Agricultural development in the lowlands is well developed and primary meadows are very limited in the southern portion of the island. Secondary forests of birch (Betula platyphylla) reed-grass, sedge's (Carex spp) and bamboo (Sasa kurilensis (Rupr.) Makino) thickets form in areas of spruce-fir forests that have been cut or fire damaged. Bogs in the south are mostly oligotriphic and occur in the Susunaiskaya and Muravyovskaya lowlands.

\section{RESEARCH BACKGROUND}

In spite of the first publications on this territory appearing more than 130 years ago (Schmidt, 1869; Lindberg, 1875), the general number of hepatics known for the entire Sakhalin Region (i.e. for Sakhalin and the Kuriles) comprises about 100 species (Gambaryan, 1993). Among those 78 are known from the island itself. Taking into account a great variety of growth conditions determined by significant latitudinal length of the territory, differences in altitudes up to $1600 \mathrm{~m}$ causing altitude zone formation, considerable difference in amount of annual precipitation between individual sections of the territory, diversity of geomorphological conditions, chemical composition of rocks etc., it is possible to consider the indicated number ( 78 species) to represent no more than a half of the actual taxonomic diversity. So the number of liverwort species growing on Sakhalin Island seems to be no less than 150 species.

Studies on liverworts of Sakhalin were started (see: Savich, 1936) by P.P. Glehn and F.B. Schmidt in the middle of XIX century. In 1860 and 1861 they made a small collection of bryophytes in the area of the Dui Bay, on the western coast of the island. Later this collection was examined by G.K. Girgensohn and published in a brief report by Schmidt (1868). It listed only one liverwort species for Sakhalin: Lepidozia reptans (L.) Dum.. Later the same collection was studied by S.O. Lindberg, and the revision results were published in 1875. The paper reported 15 species: Radula complanata, Lepidozia reptans, Blepharostoma trichophyllum, Lophozia ventricosa (as Jungermannia ventricosa var. porphyroleuca (Nees) Gottsche), Bazzania trilobata, Cephalozia connivens, Scapania irrigua (as Martinella irrigua (Nees) Lindb.), Diplophyllum taxifolium, Mylia anomala, Chilos- 
cyphus pallescens (as C. polyanthos var. pallescens (Ehrh.) Carringt.), Cephalozia bicuspidata, Calypogeia azurea (as Kantia trichomanis (L.) Gray), Porella grandiloba, Macrodiplophyllum plicatum (as Diplophyllum plicatum Lindb.) and Mylia verrucosa. The last three he described as new to science (Lindberg, 1875). Later on, Lindberg \& Arnell (1889) report 10 additional species for Sakhalin were not on the list published earlier by Lindberg.

So for the last nearly 100 years after the first publication by Schmidt there were only occasional and disembodied notes in taxonomic surveys or papers on the flora of the Far East in general, or of Japan saying that a particular species also occurs on Sakhalin. For example, L.I. Savicz (1936) reported 14 species mainly on the basis of examination of collections of A.N. Krishtafovich (gathered in 1929) and V. Korzhevin (gathered in 1926) from the west-central part of the island. Five species: Reboulia hemisphaerica (L.) Raddi, Conocephalum conicum (as Fegatella conica (L.) Corda), Pellia epiphylla, P. neesiana (as P. fabbroniana Raddi), Ptilidium ciliare and Porella vernicosa (as Madotheca vernicosa Lindb.) were new for island. Korotkevich (1952) reported Pedinophyllum interruptum (Nees) Lindb. and Blepharostoma arachnoideum M.A. Howe new for the island.

A special paper devoted to liverworts of Sakhalin appeared in 1963 (Kitagawa, 1963). The material for the article was based mostly on the collection gathered by U. Faurie in 1907 and 1908 in the southern part of the island. Kitagawa (1.c.) also summarized disembodied data published by Y. Horikawa in various issues devoted to liverworts of Japan (Horikawa, 1934, etc.). In total, the work by Kitagawa, (1963) listed 63 species, among which 23 were reported for the first time for the island.

In 1978 J. Duda (1978) published the results from collections made by Dr. V. Vasak who had traveled in the USSR. For Sakhalin, J. Duda (1.c.) reported 9 species, among which one, Calypogeia integristipula was new to the island.

Thus, by present 78 liverwort species have been reported for the island. Among this number we did not consider the species recorded in scientific reports from commercial projects, unless we examined the specimen which the species record was based on.

\section{RESULTS AND DISCUSSION}

The major material studied while preparing the paper were the specimens of liverworts col- lected in the central and southern parts of the island in 2001 by J. Harpel and V.Ya. Cherdantseva, and in the north-eastern part of the island in 2004 by K.V. Gorobets. In addition, V.A. Bakalin studied liverworts in some areas in the vicinities of Yuzhno-Sakhalinsk in 2005. Some occasional gatherings found when looking through the collections from the Russian Far East were identified and revised as well. In total we revealed 72 species, among those 34 are reported for the first time for the flora of the island. The data on liverworts from the northern part of the island has been collected for the first time. A significant share of species revealed for the first time among the general number of detected taxa, were collected by an expert-hepaticologist (it was only for a week that an expert-hepaticologist studied the liverwort flora of the island, when V.A. Bakalin visited Yuzhno-Sakhalinsk on his way to the Kurile Islands.). The remainder of the species' were found by bryologists-muscologists while conducting fieldwork that did not make it its aim to reveal the whole diversity of liverworts. Thus our understanding of the island's liverwort flora is far from complete.

Some findings are interesting in respect to phytogeography, and they are discussed below.

Calypogeia suecica is reported for the first time in the south of the Russian Far East. Earlier the area of the species (Schljakov, 1979) was considered to be European-North-American, although R.N. Schljakov (1.c.) pointed out one location in the north of the Chukotka. Schljakov (1979) noted that the specimen might have been not $C$. suecica, but rather an anomalous form of C. muelleriana. That finding has not been mentioned from then on. Later the species was found in South Siberia (Vana, Soldan, 1985). The plants in the specimen that we collected look very much typical for $C$. suecica, which is characterized by wide underleaves being twice or more as wide as stem; and small leaf cells reaching $28 \mu \mathrm{m}$ in the middle part.

Crossocalyx hellerianus has been revealed for the first time in East Asia. Its closest location is in East Siberia (Stanovoye nagorye Uplands, see Bakalin, 2004). Indeed, the species is unlikely to be rare in the coniferous forest zone in south of Siberia and the Russian Far East, because of its small size it is overlooked by collectors. 
Gymnocolea inflata was found in the south of the Russian Far East for the second time. Earlier this species, widely distributed in northern Asia (to the north of $50^{\circ}-55^{\circ}$ parallels), was known in the south of the Far East only from South Sikhote-Alin (Gambaryan, 1992). In Japan the species is substituted by the morphologically close vicariant Gymnocolea marginata (Steph.) Hatt. This species differs form $G$. inflata (Kitagawa, 1966: 113) "in the following features: the plants are less flaccid, the leaves are broader and more or less concave (sometimes even canaliculate), and the leaves are regularly arranged (leaves on shoot spread at similar angles) and dorsally secund". We do not have any material to judge on this issue, but it seems there is no doubt that additional investigation on both variable taxa needs to be carried out in order to solve the question of their segregation. According to the data we have it is the southernmost location of the species in Asia.

Isopaches bicrenatus is reported from the south of the Russian Far East for the first time. This Boreo-Arctomontane (Konstantinova, 2000) circumpolar species with a bipolar distribution seems to be rare in the South-east of Asia. At least, according to available data it has not been found in Japan, Korea and China.

Kurzia makinoana is known in Japan and Taiwan (Potemkin, 2003), and in Russia in Kamchatka (Potemkin, 2003; Bakalin, 2005), the Commander Islands (Bakalin, unpublished), the Kuriles Islands (Iturup Island) (Potemkin, 2003). The finding is the second in the south of the Russian Far East and clarifies the general distribution of the species.

Mylia nuda, an East Asian species previously known from Japan and Taiwan (Potemkin, Kazanovsky, 1993), has been revealed for the first time in Russia. In its ecology and general distribution pattern, the species is similar to $M$. verrucosa, which allowed the authors of the cited paper to treat $M$. nuda Inoue et Yang as a subspecies of $M$. verrucosa. We suppose that it is better to keep the traditional status of the taxon (Furuki, Mizutani, 1994) for two reasons. First of all, these two species significantly differ in their perianthium structure; and, second, it is much easier to unite both taxa into one, if necessary, than to divide $M$. verrucosa s.1. into two species, in case the two species' independence is fairly proven in future.
Nardia assamica is a temperate East Asian species known from south-eastern China (Piippo, 1990), Korea (Yamada, Choe, 1997), Japan (Amakawa, 1959). In Russia it is known from Kamchatka (Bakalin, 2003). In 2002 it was also found on the Commander Islands (Bakalin, unpublished). The finding fills the gap in the species distribution and is a first report for this taxon in the south of the Russian Far East.

Orthocaulis binsteadii is a species new to the south of the Russian Far East. With mostly an arctic-montane circumpolar distribution (Konstantinova, 2000), the closest location is more than 1000 $\mathrm{km}$ to the north-east on Shumshu Island (the northern end of the Kuriles Chain). According to the data available the collection represents the southernmost location in Asia.

Nipponolejeunea subalpina was reported from Sakhalin from the Kimonai area (probably the southern part of the island) (Kitagawa, 1963), and that was the only locality of the genus in Russia, until our recent finding (see below). The genus Nipponolejeunea includes 2 species of East Asian distribution. Morphologically the genus is characterized by shoots of lejeuneoid appearance with slightly lengthways conduplicate leaves, with dorsal lobe loosely imbricate and ciliate on dorsal side, regular underleaves and dioicous inflorescence. Nipponolejeunea pilifera (Steph.) S. Hatt. is known from Japan, Korea and Taiwan, and $N$. subalpina from Korea, Japan, Taiwan and Sakhalin. The morphological description of $N$. subalpina (based mainly on Mizutani, 1961, and our material) is as the follow: Plants pale-green. Shoots up to $10 \mathrm{~mm}$ long and $0.6-0.8 \mathrm{~mm}$ wide. Cross-section of the stem 4-5 cells in diameter with a circle about 15 cortical cells; all cells thickwalled with distinct trigones. Leaves approximate to slightly imbricate; the lobe clearly convex, about $0.3 \mathrm{~mm}$ long and $0.2-0.25 \mathrm{~mm}$ wide, the dorsal margin with $1-5$ cilia of $1-5$ cells long; leaf-lobule 3/4-1 length of the lobe, inflated along keel, the apex with 2 teeth, the first tooth 1-3 cells long and 1-2 cells wide at base, the second tooth unistratose 1-3 cells long. Median cells on leaflobe $15-20 \mu \mathrm{m}$ in diameter, with thin- to rather thick-walled, trigones minute and concave to large and convex, cuticle smooth; oil-bodies 3-4, occasionally 5 per cell, somewhat grayish, elliptical, $4.5 \times 2.5 \mu \mathrm{m}$. Underleaves $2-3$ times as wide 


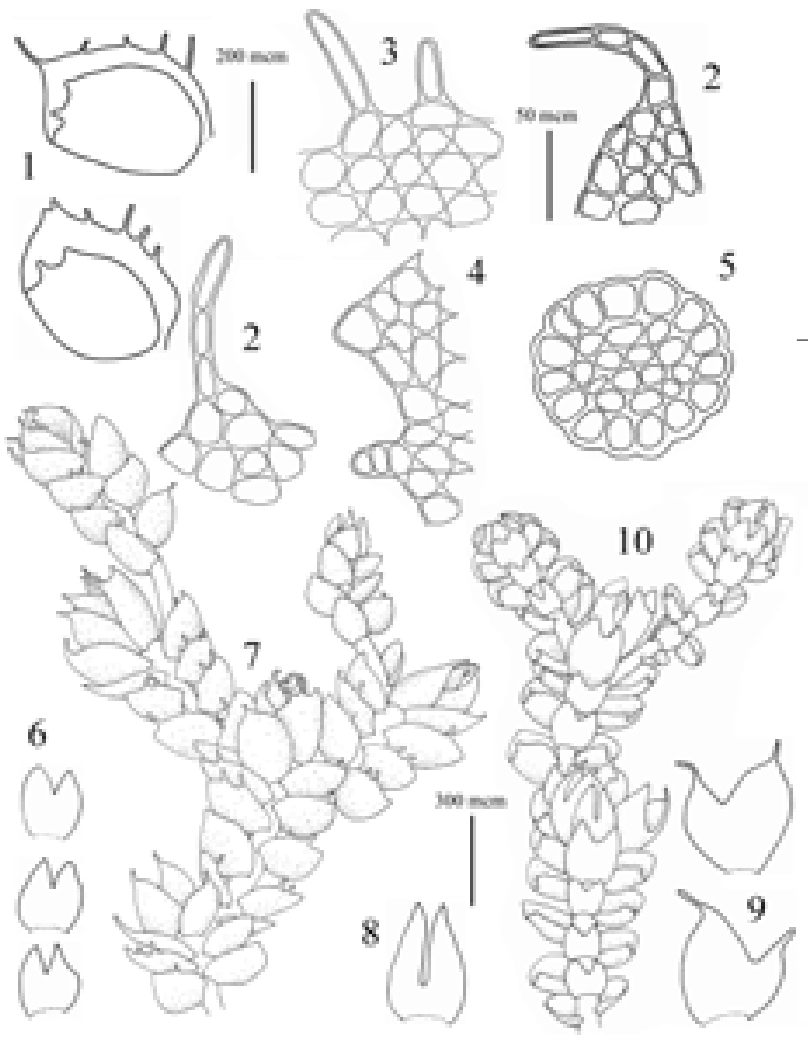

Fig. 1. Nipponolejeunea subalpina (Horik.) Hatt. (from Sakhalin Island, southwestern part, Harpel \& Cherdantseva 29.VII.2001 KPABG-105786): 1 leaves, ventral view; 2 - ending of lobes; 3 - dorsal margin of lobe; 4 - ending of lobule; 5 - cross section of the stem; 6 - underleaves; 7 - shoot, dorsal view; 8 - bracteole; 9 - female bracts; 10 - shoot, ventral view. Scales: $300 \mu \mathrm{m}$ - for $6-10 ; 200 \mu \mathrm{m}$ - for $1 ; 50 \mu \mathrm{m}-$ for 2-5.

are usually about $1.5 \mathrm{~mm}$ wide) and underleaves no more than 3 times wider than stem (in $N$. pilifera underleaves are 5-6 times wider than stem).

\section{LIST OF SPECIES}

The species names correspond to that accepted in the Check-list of the Hepaticae and Anthocerotae of the former USSR (Konstantinova et al., 1992). After the species name it is indicated occurrence in our material plants with antheridia (ant.), archegonia (arch.), perianthia (per.) and gemmae (gemm.). After that there is its distribution over the island territory according to the collection identification results, with the fol- as the stem, orbicular to oval, bilobate with entire margin. Dioicous. Male inflorescence intercalary or occasionally terminal on a branch, male bracts usually in 3-5 pairs, inflated, bracteoles similar with underleaves. Female inflorescence terminal on the stem or on elongate lateral branch, mostly with 1-2 innovations just below the bracts, Female bracts in 2-3 pairs, the lobe frequently ended by cilia 3-6 cells long, bracteoles similar with underleaves, but more big and with deeper sinus. Perianth pyriform, about $1 \mathrm{~mm}$ long and $0.7 \mathrm{~mm}$ wide, 3-keeled, archegonium mostly one per perianth. Seta not articulate, the outer cells in 16 longitudinal rows, the inner cells in 4 rows. Cells of the outer layer of capsule wall with brownish, nodular intermediate thickenings and trigones on the radial wall; cells of inner layer with an irregular net-like work of brown thickenings on the inner wall. Elaters dark brown, 140-200 $\mu \mathrm{m}$ long, $20 \mu \mathrm{m}$ wide, unispiral, spores about 40-50×35$40 \mu \mathrm{m}$, minutely papillose (Fig. 1).

The species differs from Nipponolejeunea pilifera in smaller size of plants, their shoots do not exceed $0.8 \mathrm{~mm}$ wide (while in $N$. pilifera shoots lowing abbreviations: $\mathbf{N}$ - Northern part of the island; $\mathbf{C}$ - Central part of the island; S-W - Southwestern part of the island; $\mathbf{S}$-Southern part of the island (Fig. 2.). In division of Sakhalin into four parts we follow to A.I. Tolmachyov (1955). N means subzone of Larch forests prevailing, $\mathbf{C}$ forests with Spruce prevailing, $\mathbf{S}$ - forests with Fir prevailing and $\mathbf{S}-\mathbf{W}$ - coniferous forests with admixture temperate broad-leaved trees. Last names of the collectors are provided wholly, with the exception of the following abbreviations: $\mathrm{JH}-$ J. Harpel, VC - V.Ya. Cherdantseva; KG K.V. Gorobets; VB - V.A. Bakalin. Further, the collection dates of selected specimens are provided. The cited specimens are preserved in the herbaria (KPABG or VLA), which is indicated after the collection date. In case of the specimen's being in KPABG the herbarium numbers are provided as well, they are given in compliance with the registration notes in the Herbarium Data Base. At the end there are environmental conditions in which the species was found. Species being new to the island are marked with asterisk before the name of the taxon. 


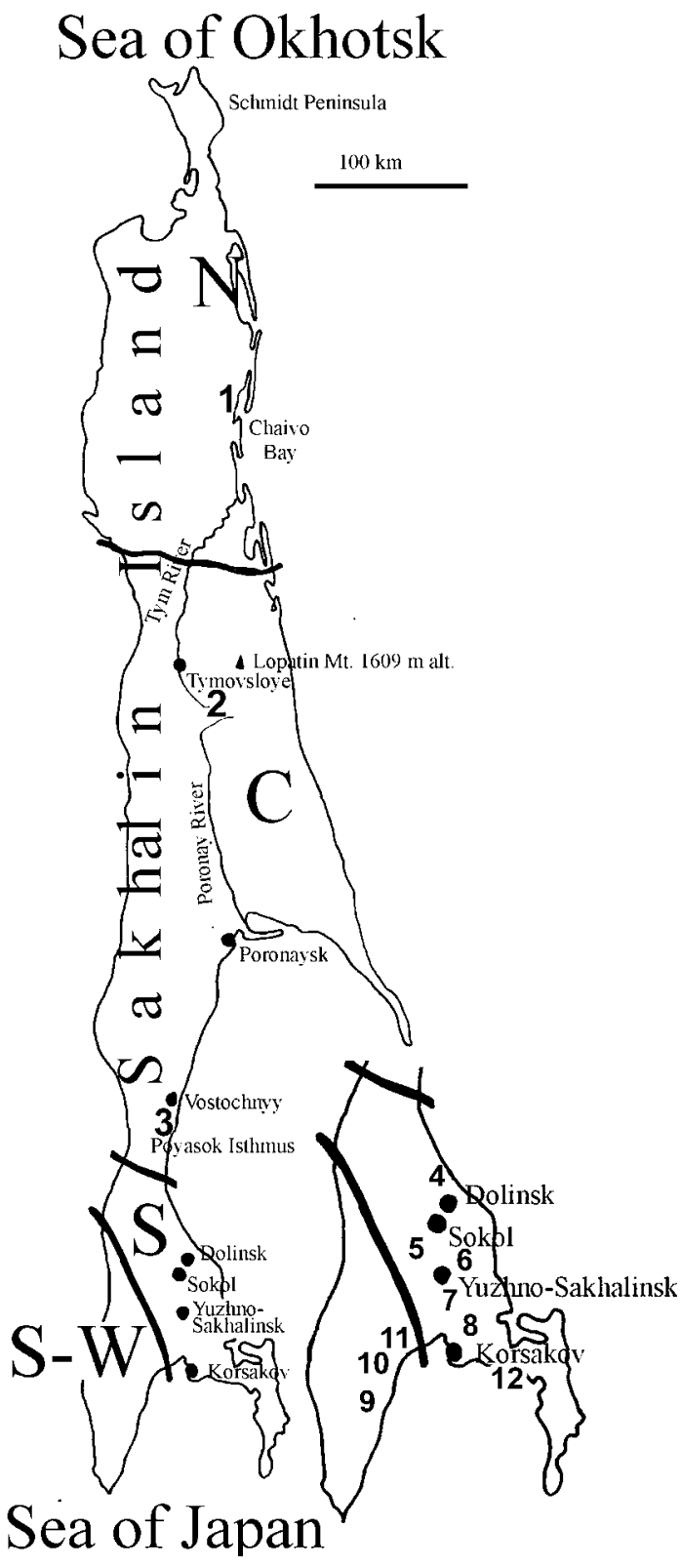

Fig. 2. Map of Sakhalin Island with marked topographic units used in labels as well as numbers of more well studied collecting localities. \#1 - Chaivo Bay - залив Чайво; \#2 Tym River - pека Тымь; \#3 - 25 km South of Vostochnyy Town - 25 км южнее поселка Восточный; \#4 - Lebyazhye Lake and Nayba River - озеро Лебяжье и река Найба; \#5 Yuzhno-Sakhalinsk mud volcano - Южно-Сахалинский грязевой вулкан (17 km NW of Yuzhno-Sakhalinsk); \#6 Rogatka River- река Рогатка; \#7 - Mayorskaya Mt. - гора Майорская; \#8 - Vysokaya Village - деревня Высокая; \#9 Uspenskoye Village - деревня Успенское; \#10 - Tunaycha Lake Area - район озера Тунайча; \#11 - Lososey Inlet Area - район Залива Лососей; \#12 - Chibisanskoye Lake and Mereya River - Чибисанское озеро и река Мерея.
*Anastrophyllum michauxii (F.Web.) H. Buch - C: \#2 JH\&VC 8.VIII.2001 (KPABG-105788) - on a decay rotten log in full sun at the base of the talus slope. *Barbilophozia hatcheri (A.W. Evans) Loeske-gemm. - C: Mt. Karakul'chen I.F. Skirina, N.A. Tsarenko 31.VII.2004 (VLA) - Betula forest, on soil. With Sphenolobus saxicola.

Bazzania trilobata (L.) S.Gray - S-W: \#10 JH\&VC 29.VII.2001 (KPABG-105774); S: Aniva Bay, near Prigorodnoye N.A. Tsarenko, V.M. Peshekhodko, R.V. Doudkin 30.VI.2000 (VLA) 2.VII.2000 (VLA); \#6 VB 31.VIII.2005 (VLA) - in a wet second growth coniferous forest, on decaying wood; oligotrophic peat bog, among Sphagnum mats.

Blasia pusilla L. - S-W: \#10 JH\&VC 29.VII.2001 (KPABG-105810), [Parusnaya River O. Zakharova 12.X.1967 (VLA) - probably located in S] - on roadsides in wet forests. Once with Schistochilopsis incisa.

Blepharostoma trichophyllum (L.) Dumort. - per. - SW: \#10. JH\&VC 29.VII.2001 (KPABG-105802); S: \#12 JH\&VC 28.VII.2001 (KPABG-105722); \#7 VB 3.IX.2005 (VLA); \#9 VB 31.VIII.2005 (VLA); \#5 VB 4.IX.2005 (VLA) - in spruce and fir forests, on decaying wood. With Calypogeia integristipula, Lepidozia reptans and Macrodiplophyllum plicatum.

Calypogeia integristipula Steph. - N: \#1 KG 3.VIII.2004 (VLA), same, KG 1.VIII.2004 (VLA); C: \#3 JH\&VC 2.VIII.2001 (KPABG-105776); S-W: \#10 JH\&VC 29.VII.2001 (KPABG-105791); S: Sokol Town Area JH\&VC 18.VIII.2001 (KPABG-105738); \#6 JH\&VC 22.VII.2001 (KPABG-105792); \#12 JH\&VC 28.VII.2001 (KPABG-105773); \#8 JH\&VC 25.VII.2001 (KPABG105777); \#4 JH\&VC 23.VII.2001 (KPABG-105778); \#7 VB 3.IX.2005 (VLA); \#11 VB 7.IX.2005 (VLA); \#9 VB 1.IX.2005 (VLA); \#5 VB 4.IX.2005 (VLA); - in coniferous and mixed forests, on decaying wood and along the side of a shallow depression; raised dwarfschub-peat-moss mire, on Sphagnum; in the north of the island in Japanese stone pine thickets. With Lepidozia reptans, Blepharostoma trichophyllum, Cephalozia lunulifolia, Cephalozia connivens, Cephaloziella divaricata, Mylia anomala and Kurzia makinoana. ${ }^{*}$ C. muelleriana (Schffn.) Müll.Frib. - S: \#6 VB 31.VIII.2005 (VLA); \#5 VB 4.IX.2005 (VLA) moist decaying wood in spruce and fir forest. With a number of epixylous species: Blepharostoma trichophyllum, Lophocolea heterophylla, Lepidozia reptans, Ptilidium pulcherrimum, Crossocalyx hellerianus, Mylia verrucosa, Cephalozia leucantha, $C$. pleniceps, Metzgeria conjugata, Riccardia latifrons and Lophozia ventricosa var. longiflora.

C. neesiana (C. Mass. et Carest.) Müll. Frib. - S: YuzhnoSakhalinsk, Zmyeevka River A.G. Mikulin 5.XI.1987 (VLA) - in Abies-Picea forest, on decaying wood.

C. sphagnicola (Arnell et J. Perss.) Warnst. et Loeske 
- S: \#11 VB 7.IX.2005 (VLA) - moss and dwarf shrub swamp, hummocks overgrown with Ledum. A top of Sphagnum mats, with Cephalozia lunulifolia. ${ }^{*}$ C. suecica (Arnell et J. Perss.) Müll.Frib. - S: \#6 VB 31.VIII.2005 (VLA) - moist, almost decomposed stump in spruce forest. With Lophocolea heterophylla and Mylia verrucosa.

Cephalozia bicuspidata (L.) Dumort. - ant., per., arch. S: \#12 JH\&VC 28.VII.2001 (KPABG-105775); \#6 JH\&VC 22.VII.2001 (KPABG-105813); \#11 VB 7.IX.2005 (VLA) - in a Picea glehni forest and in the Sasa kurilensis bamboo section on the soil trail bank in part shade; on moist decaying wood along the bank of a stream in willow and birch forest. With Chiloscyphus polyanthos, Lophocolea heterophylla, Lophozia ventricosa var. guttulata and Lepidozia reptans.

C. connivens (Dicks.) Lindb. - N: \#1 KG 3.VIII.2004 (VLA) - raised oligotrophic dwarf-shrubs-peat-moss bog. With Mylia anomala, Cephaloziella divaricata, Calypogeia integristipula.

C. leucantha Spruce - S: \#5 VB 4.IX.2005 (VLA) decaying wood in fir forest. With epixylous Blepharostoma trichophyllum, Lophocolea heterophylla, Lepidozia reptans, Crossocalyx hellerianus, Mylia verrucosa, Cephalozia leucantha, C. lunulifolia, Riccardia palmata and Macrodiplophyllum plicatum.

${ }^{*} C$. cf. loitlesbergeri Schiffn. - N: \#1 KG 1.VIII.2004 (VLA) - raised oligotrophic dwarf-shrubs-peat-moss bog. With Kurzia makinoana, Calypogeia integristipula. The record based on sterile plants, so there are some doubts in this identification.

${ }^{*}$ C. lunulifolia (Dumort.) Dumort. - per., ant. - S: \#6 JH\&VC 22.VII.2001 (KPABG-105789), same, VB 31.VIII.2005 (VLA); \#7 VB 3.IX.2005 (VLA); \#11 VB 7.IX.2005 (VLA); \#9 VB 1.IX.2005 (VLA); \#5 VB 4.IX.2005 (VLA) - in coniferous forests on moist decaying wood; Japanese stone pine thickets in moist thickly shaded rocks of northern exposition. With Macrodiplophyllum plicatum, Diplophyllum taxifolium, Lophozia ventricosa var. guttulata; in bog on top of Sphagnum, along with Calypogeia sphagnicola; on decaying wood along with Calypogeia integristipula, Crossocalyx helerianus, Lophocolea heterophylla, Cephalozia leucantha, Mylia verrucosa and Lepodozia reptans.

*C. pleniceps (Aust.) Lindb. - S: \#5 VB 4.IX.2005 (VLA) - on decaying wood along the stream bed (splashed by the high water) in fir and birch forest. With Blepharostoma trichophyllum and Calypogeia muelleriana.

Cephaloziella divaricata (Sm.) Schiffn.- per., gemm. - N: \#1 KG 3.VIII.2004 (VLA) - raised oligotrophic dwarf-shrubs-peat-moss bog. With Cephalozia connivens, Mylia anomala, Calypogeia integristipula.

*Chiloscyphus fragilis (A.Roth) Schiffn. - S: \#6 VB 31.VIII.2005 (VLA) - on a stone, splashed with high wa- ter, on the river bank, the bank of a drying up slow stream. C. polyanthos (L.) Corda-S: Sokol Town Area JH\&VC 17.VII.2001 (KPABG-105790); \#6 JH\&VC 22.VII.2001 (KPABG-105752), same, VB 31.VIII.2005 (VLA); \#11 VB 7.IX.2005 (VLA); \#5 VB 4.IX.2005 (VLA) - along old road in forest; on moist decaying wood in spruce and fir forest; on the loamy bank of a stream in deep shade of Petasites and Filipendula kamtschatica in spruce and birch forest. In pure mats or (on decaying wood on stream banks) along with Lophocolea minor, Calypogeia integristipula, Lepidozia reptans, Metzgeria conjugata, Riccardia chamaedryfolia.

Conocephalum conicum (L.) Underw. - C: \#3 JH\&VC 2.VIII.2001 (KPABG-105794); S: Sokol Town Area JH\&VC 17.VII.2001 (KPABG-105795), same, JH\&VC 18.VII.2001 (KPABG-105796), same, VB 31.VIII.2005 (VLA), same, 19.VII.2001 (KPABG105797); \#5 VB 4.IX.2005 (VLA) - in a deep ravine with a seasonal creek, along old road in forest, on the soil bank along the river; on decayed wood in full to part shade; on humus in a stream bed shaded by Filipendula kamtschatica in fir and birch forest.

C. japonicum (Thunb.) Grolle - gemm. - S: \#5 VB 4.IX.2005 (VLA) - on the loamy bank of a stream in deep shade of Petasites and Filipendula kamtschatica in spruce and birch forest. With Pellia neesiana.

*Crossocalyx hellerianus (Nees ex Lindenb.) Meyl. per., gemm. - S: \#5 VB 4.IX.2005 (VLA) - decaying wood in fir forest. With epixylous Lepidozia reptans, Ptilidium pulcherrimum, Mylia verrucosa, Cephalozia leucantha, C. lunulifolia, Metzgeria conjugata, Riccardia latifrons, Lophozia ventricosa var. longiflora, Macrodiplophyllum plicatum, Blepharostoma trichophyllum.

Diplophyllum taxifolium (Wahlenb.) Dumort. - per., gemm. - C: along the Uskovo River about $12 \mathrm{~km}$ north northeast of Tymovskoye JH\&VC 6.VIII.2001 (KPABG-105800); \#2 JH\&VC 8.VIII.2001 (KPABG105804); \#3 JH\&VC 2.VIII.2001 (KPABG-105803); S: \#6 VB 31.VIII.2005 (VLA); \#7 VB 3.IX.2005 (VLA); \#5 VB 4.IX.2005 (VLA) - in the coniferous and mixed forests on decaying wood; in Japanese stone pine thickets in moist thickly shaded rocks of northern exposition.

*Frullania bolanderi Austin - per. - C: along the Uskovo River about $12 \mathrm{~km}$ north northeast of Tymovskoye, at the west base of Kasatkina Mt., across the river from the washed out bridge JH\&VC 7.VIII.2001 (KPABG105760); \#2 JH\&VC 7.VIII.2001 (KPABG-105764); S: about $34 \mathrm{~km}$ Southeast of Yuzhno-Sakhalinsk JH\&VC 25.VII.2001 (KPABG-105755); Sokol Town Area JH\&VC 20.VII.2001 (KPABG-105758), same, JH\&VC 16.VII.2001 (KPABG-105759); \#5 VB 4.IX.2005 (VLA) - in part shade on Salix udensis and Chosenia arbutifolia (Pall.) A. Skvorts. trees along 
the edge of an agricultural field, on a Quercus crispula tree trunk in broad-leaved forest; in a mixed coniferous forest in the floodplain along the river tree trunk of Betula, Chosenia arbutifolia.

F. inflata Gottsche - ant., arch., per. - C: \#3 JH\&VC 2.VIII.2001 (KPABG-105762); S: \#12 JH\&VC 28.VII.2001 (KPABG-105757) - in coniferous forests on decaying wood.

${ }^{*}$ F. koponenii Hatt. - ant., arch., per. - S: \#6 VB 31.VIII.2005 (VLA) - on the bark of the alder (as high as $1.5 \mathrm{~m}$ ) in moist alder forest with tall herbs.

F. muscicola Steph. - ant., arch., per. - C: Poronaysk Town Area JH\&VC 4.VIII.2001 (KPABG-105751); S: \#4 JH\&VC 23.VII.2001 (KPABG-105756); \#12 JH\&VC 28.VII.2001 (KPABG-105766); Sokol Town Area JH\&VC 17.VII.2001 (KPABG-105768) - in the Quercus and Picea-Abies forests, on tree trunks. With Radula complanata.

*Geocalyx graveolens (Schrad.) Nees - per. - S: \#9 VB 1.IX.2005 (VLA) - moist larch forest with ferns and herbs, fire damaged on moist decaying roots of half decomposed (cut down) stump of the larch. In pure mats or with Lophozia silvicola and Lepidozia reptans.

* Gymnocolea inflata (Huds.) Dumort. - N: \#1 KG 4.VIII.2004 (VLA) - in wet Larix forest with hygrophilous sedges, on soil.

Harpanthus flotovianus (Nees) Nees - N: \#1 KG 14.VIII.2004 (VLA), same, KG 7.VIII.2004 (VLA) (mod. integrifolia); S: \#9 VB 1.IX.2005 (VLA) - in Larix forests, on humus near the stream and half decomposed (cut down) stump of the larch.

*Isopaches bicrenatus (Schmid. ex Hoffm.) H. Buch. - ant., per., gemm. - N: \#1 KG 4.VIII.2004 (VLA); S: \#6 VB 31.VIII.2005 (VLA) - Larix forest damaged by fire, on fine-grained soil, on the side of a forest road in spruce forest.

*Kurzia makinoana (Steph.) Grolle - N: \#1 KG 1.VIII.2004 (VLA) - raised oligotrophic dwarfshrub-peat-moss mire, among mosses. With Cephalozia cf. loitlesbergeri, Calypogeia integristipula.

Lepidozia reptans (L.) Dumort. - C: \#3 JH\&VC 2.VIII.2001 (KPABG-105798); S-W: \#10 JH\&VC 29.VII.2001 (KPABG-105799); S: \#4 JH\&VC 23.VII.2001 (KPABG105807);\#12 JH\&VC 28.VII.2001 (KPABG-105809); \#6 JH\&VC 22.VII.2001 (KPABG-105814);\#7 VB3.IX.2005 (VLA); \#11 VB 7.IX.2005 (VLA); \#5 VB 4.IX.2005 (VLA) - in coniferous forests, on decaying wood; in the Sasa kurilensis bamboo section of the trail on the soil trail bank. With Lophozia ventricosa var. guttulata, Blepharostoma trichophyllum, Calypogeia integristipula, Macrodiplophyllum plicatum and Cephalozia bicuspidata.

Liochlaena subulata (Evans) Schljak. - gemm. - S: \#5 VB 4.IX.2005 (VLA) - on decaying wood along the stream bed (splashed by the high water) in fir and birch forest.
*Lophocolea bidentata (L.) Dumort. - N: \#1 KG 14.VIII.2004 (VLA) - Abies-Picea forest with Leptorumohra amurensis (Christ.) Tzvel., on water soaked decaying wood among mosses.

L. heterophylla (Schrad.) Dumort. - ant., per. - S-W: \#10 JH\&VC 29.VII.2001 (KPABG-105820); S: Sokol Town Area 20.VII.2001 (KPABG-105818), same, JH\&VC 17.VII.2001 (KPABG-105819); Korsakov Distr. O.F. Skirina 21.VII.2004 (VLA); \#11 VB 7.IX.2005 (VLA); \#5 VB 4.IX.2005 (VLA) - in mixed forest on base of an Alnus hirsuta and an Betula ermanii trees; along river, on mineral soil along a shallow ditch bank; in a shallow ravine with a perennial stream in a mixed coniferous forest. With Ptilidium pulcherrimum and Metzgeria furcata.

L. minor Nees - gemm. - S: \#11 VB 7.IX.2005 (VLA) on moist decaying wood along the bank of a stream in willow and birch forest. With Chiloscyphus polyanthos.

*Lophozia silvicola $\mathrm{H}$. Buch - gemm. - S: \#9 $4 \mathrm{~km}$ east of the village, VB 1.IX.2005 (VLA) - moist larch forest with ferns and herbs, fire damaged, on moist decaying roots of half decomposed (cut down) stump of the larch. With Geocalyx graveolens.

L. ventricosa (Dicks.) Dumort. var. guttulata (Lindb. et H.W. Arnell) Bakalin - per., ant. - C: \#3 JH\&VC 2.VIII.2001 (KPABG-105798), same, JH\&VC 2.VIII.2001 (KPABG-105823); S: \#6 JH\&VC 22.VII.2001 (KPABG-105813); \#7 VB 3.IX.2005 (VLA); \#9 VB 1.IX.2005 (VLA); \#5 VB 4.IX.2005 (VLA) - in coniferous forests, on decaying wood; in the Sasa kurilensis bamboo section of the trail on the soil trail bank. With Lepidozia reptans, Cephalozia bicuspidata, Lepidozia reptans and Mylia verrucosa. _ var. longiflora (Nees) Macoun -S: \#5 VB 4.IX.2005 (VLA) - on decaying wood along the stream bed (splashed by the high water) in fir and birch forest. With epixyles: Riccardia latifrons, Cephalozia lunulifolia, Calypogeia muelleriana and Blepharostoma trichophyllum.

Macrodiplophyllum plicatum (Lindb.) H.Perss. gemm. - N: \#1 KG 14.VIII.2001 (VLA); C: Poronaysk Town Area JH\&VC 8.VIII.2001 (KPABG105816); about 24 to $34 \mathrm{~km}$ East-southeast of Tymovskoye JH\&VC 8.VIII.2001 (KPABG-105822); \#3 JH\&VC 2.VIII.2001 (KPABG-105830); I.F. Skirina, N.A. Tsarenko 1.VIII.2004 (VLA); S-W: \#10 JH\&VC 29.VII.2001 (KPABG-105808); S: \#12 JH\&VC 28.VII.2001 (KPABG-105831); \#4 JH\&VC 23.VII.2001 (KPABG-105832); \#7 VB 3.IX.2005 (VLA); \#9 VB 1.IX.2005 (VLA); \#5 VB 4.IX.2005 (VLA) - in coniferous and mixed forests, on decaying wood and ground. With most epyxiles such as Lophocolea heterophylla, Crossocalyx hellerianus, Mylia verrucosa, Cephalozia leucantha, Blepharostoma trichophyllum and Lepidozia reptans. 
Marchantia polymorpha L. - N: \#1 KG 2.VIII.2004 (VLA); C: \#2 JH\&VC 7.VIII.2001 (KPABG-105824) - in a mixed coniferous forest along the river, on soil along the river bank in part to full shade; in mesophytic larch forests with low herbs, on soil by the creek.

Metzgeria conjugata Lindb. - ant., arch. - S: \#7 VB 3.IX.2005 (VLA); \#5 VB 4.IX.2005 (VLA) - fir forest, on shaded vertical walls of boulders down the slope, on decaying wood along the stream bed (splashed by the high water) in fir and birch forest. With Porella vernicosa, Ptilidium pulcherrimum, Riccardia palmata, R. chamaedryfolia and Chiloscyphus polyanthos.

* M. furcata (L.) Dumort. - S: Sokol Town Area JH\&VC 28.VII.2001 (KPABG-105827), same, JH\&VC 17.VII.2001 (KPABG-105828) - on a small rock along the hillside, along old road in forest along the river on soil over duff at the base of a birch tree. With Lophocolea heterophylla.

Mylia anomala (Hook.) S. Gray - gemm. - N: \#1 KG 2.VIII.2004 (VLA), same, KG 3.VIII.2004 (VLA); S: \#11 VB 7.IX.2005 (VLA); \#11 VB 7.IX.2005 (VLA) - in raised oligotrophic sedge-peat-moss and dwarf-shrub-peat-moss mires among Sphagnum; Sphagnum and dwarf shrub (Oxycoccus, Myrica, Ledum) swamp, hummocks; in wet larch forest with peat-moss cover, among Sphagnum.

*M. nuda Inoue et Yang - per. - S: \#6 VB 31.VIII.2005 (VLA) - moist, almost decomposed stump in spruce forest with no ground cover.

M. verrucosa Lindb. - per. - C: \#3 JH\&VC 2.VIII.2001 (KPABG-105823); S: \#5 VB 4.IX.2005 (VLA) - in the Abies, Betula forest on the ridge on a decay rotten stump in part shade along the edge of the forest. With Lophozia ventricosa var. guttulata, Blepharostoma trichophyllum, Lophocolea heterophylla, Lepidozia reptans, Crossocalyx hellerianus, Cephalozia leucantha, C. lunulifolia and Macrodiplophylluym plicatum.

*Nardia assamica (Mitt.) Amak. - per. - C: \#3 JH\&VC 1.VIII.2001 (KPABG-105781); S: Sokol Town Area JH\&VC 18.VII.2001 (KPABG-105780), same, JH\&VC 17.VII.2001 (KPABG-105783) - in a shallow ravine with a perennial stream in a mixed coniferous forest; in Abies-Betula forest on part of a soil crust formation along the dirt road.

Nipponolejeunea subalpina (Horik.) Hatt. - ant., per.S-W: \#10 JH\&VC 29.VII.2001 (KPABG-105786) in mixed forest on an Abies sachalinensis tree trunk in part shade.

*Orthocaulis attenuatus (Mart.) Evans - gemm. - C: \#2 JH\&VC 8.VIII.2001 (KPABG-105728) - on the base of a Pinus pumila in full shade. With Ptilidium californicum.

*O. binsteadii (Kaal.) H. Buch - N: \#1 KG 7.VIII.2004 (VLA) - in larch forest with lichens, Phyllodoce and dwarf-pine underbrush, on the base of the trunk of Pinus pumila.

Pellia endiviifolia (Dicks.) Dumort. - per. - S: Sokol Town Area JH\&VC 18.VII.2001 (KPABG-105741) - in a shallow ravine with a perennial stream in a mixed coniferous forest, on wet soil and decayed wood in a seasonal creek in part to full shade.

P. neesiana (Gottsche) Limpr. - per. - S: Sokol Town Area JH\&VC 19.VII.2001 (KPABG-105742); S:\#12 JH\&VC 28.VII.2001 (KPABG-105720); \#8 JH\&VC 26.VII.2001 (KPABG-105727); \#6 VB 31.VIII.2005 (VLA); \#9 VB 1.IX.2005 (VLA); \#5 VB 4.IX.2005 (VLA) - in coniferous and Alnus forest, on humus and clay soil along the river bank; on the loamy bank of a stream in deep shade of Petasites and Filipendula kamtschatica in spruce and birch forest. Sometimes with Conocephalum japonicum.

*Plectocolea infusca Mitt. var. ovalifolia Amak. - per. - C: \#3 JH\&VC 2.VIII.2001 (KPABG-105782) - in a deep ravine with a seasonal creek, on rocks along the creek bank in a seepy area.

*P. hyalina (Lyell) Mitt. - S: Sokol Town Area JH\&VC 16.VII.2001 (KPABG-105726) - on soil and rocks in a seasonally wet shallow depression along the road in part shade.

Porella vernicosa Lindb. - S: \#7 VB 3.IX.2005 (VLA); \#5 VB 4.IX.2005 (VLA) - the base of the northern slope of cliff, moist (occasionally moistened) rock crevices, outside the shade in cracks on fine soil; on the roots of fallen birch lying in a stream bed in fir and birch forest. With Sphenolobus minutus, Radula constricta and Metzgeria conjugata.

*Ptilidium californicum (Aust.) Pears. - S-W: Sokol Town Area JH\&VC 17.VII.2001 (KPABG-105735); C: \#2 JH\&VC 8.VIII.2001 (KPABG-105737) - along old road in forest along the river, on the base of a Betula platyphylla tree and Pinus pumila branches. With Orthocaulis attenuatus and Ptilidium pulcherrimum.

P. ciliare (L.) Hampe - S: \#4 JH\&VC 23.VII.2001 (KPABG-105736); along the Korsakov-Ozerskiy Hwy. JH\&VC 28.VII.2001 (KPABG-105761); \#7. VB 3.IX.2005 (VLA) - in the Pinus pumila beach forest, on litter and duff; in a Pinus sylvestris plantation, on soil; the base of the northern slope of the volcanic protrusion, moist (occasionally moistened) rock crevices, outside the shade in cracks on fine soil. With Sphenolobus minutus and Tetralophozia setiformis or in pure mats.

P. pulcherrimum (G.Web.) Vain. - per. - N: \#1 KG 31.VII.2004 (VLA), same, KG 1.VIII.2004 (VLA); C: \#2 JH\&VC 7.VIII.2001 (KPABG-105745); along the Uskovo River about $12 \mathrm{~km}$ north northeast of Tymovskoye JH\&VC 6.VIII.2001 (KPABG-105746); Poronaysk Town Area JH\&VC 4.VIII.2001 (KPABG105747); S-W: \#10 JH\&VC 29.VII.2001 (KPABG- 
105730); S: \#10 JH\&VC 29.VII.2001 (KPABG105725); Sokol Town Area JH\&VC 17.VII.2001 (KPABG-105732), same, JH\&VC 17.VII.2001 (KPABG-105733); \#7 VB 3.IX.2005 (VLA) - in the forests of different types, on trunks and branches of living trees and decaying wood. With Lophocolea heterophylla and Ptilidium californicum.

Radula complanata (L.) Dumort. - per., ant. - C: along the Uskovo River, about $12 \mathrm{~km}$ NNE of Tymovskoye JH\&VC 6.VIII.2001 (KPABG-105749); S: Sokol Town Area JH\&VC 17.VII.2001 (KPABG-105768) - on trunks of Populus sp. and Alnus hirsuta in forests along the river. With Frullania muscicola.

*R. constricta Steph. - ant. - S: \#7. VB 3.IX.2005 (VLA) - the base of the northern slope of the volcanic protrusion, moist (occasionally moistened) rock crevices, outside the shade in cracks, on fine soil. With Sphenolobus minutus and Porella vernicosa.

* Riccardia chamaedryfolia (With.) Grolle - ant., arch. - S: \#5 VB 4.IX.2005 (VLA) - on decaying wood along the stream bed (splashed by the high water) in fir and birch forest; on the loamy bank of a stream in deep shade of Petasites and Filipendula kamtschati$c a$ in spruce and birch forest. With Mylia verrucosa, Blepharostoma trichophyllum, Metzgeria conjugata, Chiloscyphus polyanths and Conocephalum conicum.

* R. latifrons (Lindb.) Lindb. - ant., arch. - S: \#5 VB 4.IX.2005 (VLA) - decaying wood in fir forest. With epixyles: Cephalozia leucantha, C. lunulifolia, Lepidozia reptans, Mylia verrucosa, Lophozia ventricosa var. guttulata and var. longiflora, Blepharostoma trichophyllum and Calypogeia muelleriana.

R. palmata (Hedw.) Carruth. - ant., arch. - S: \#6 JH\&VC 22.VII.2001 (KPABG-105721); \#5 VB 4.IX.2005 (VLA) - in part shade on a small log in the creek and on soil along the creek; decaying wood in fir forest. With Chiloscyphus polyanthos in wet places, and as an epixyle with Metzgeria conjugata, Crossocalyx hellerianus, Mylia verrucosa, Lepidozia reptans and Blepharostoma trichophyllum.

Scapania irrigua (Nees) Nees - C: \#3 JH\&VC 1.VIII. 2001 (KPABG-105793) - along a dirt road under the power lines on soil in a wet seepage area along the road in road in full sun. With Scapania paludosa.

*S. paludosa (Müll. Frib.) Müll. Frib. - C: \#3 JH\&VC 1.VIII.2001 (KPABG-105793) - along a dirt road under the power lines on soil in a wet seepage area along the road in road in full sun. With Scapania irrigua.

*S. parvifolia Warnst. - gemm. -S: \#6 VB 31.VIII.2005
(VLA) - moist mixed-spruce-deciduous forest with herbs on the slope to the stream, on moist stone in fern thickets.

Schistochilopsis incisa (Schrad.) Konstantinova-gemm. - [Parusnaya River O. Zakharova 12.X.1967. (VLA). Unfortunately, we could not find the location of the river.] - in birch forest, on soil. With Blasia pusilla.

*Solenostoma sphaerocarpum (Hook.) Steph. - per., ant. - S: \#7 VB 3.IX.2005 (VLA) - Japanese stone pine thickets, in moist thickly shaded rocks of northern exposition. With Diplophylluym taxifolium and Macrodiplophyllum plicatum.

*Sphenolobus minutus (Schreb.) Berggr. - gemm. - S: \#7. VB 3.IX.2005 (VLA) - the base of the northern slope of the volcanic protrusion, moist (occasionally moistened) rock crevices, outside the shade, in cracks on fine soil. With Sphenolobus saxicola, Tetralophozia setiformis and Macrodiplophyllum plicatum.

S. saxicola (Schrad.) Steph. - C: Mt. Karakyl'chan I.F. Skirina, N.A. Tsarenko 31.VII.2004 (VLA); S: \#7. VB 3.IX.2005 (VLA) - in birch forest, on soil; the base of the northern slope of the volcanic protrusion, moist (occasionally moistened) rock crevices, outside the shade in cracks on fine soil. With Barbilophozia hatcheri, Sphenolobus minutus, Tetralophozia setiformis and Macrodiplophyllum plicatum.

*Tetralophozia setiformis (Ehrh.) Schljakov-S: \#7 VB 3.IX.2005 (VLA) - the base of the northern slope of the volcanic protrusion, moist (occasionally moistened) rock crevices, outside the shade in cracks on fine soil. With Sphenolobus saxicola, S. minutus and Macrodiplophyllum plicatum.

*Tritomaria exsecta (Schmid. ex Schrad.) Loeske gemm. - S: \#5 VB 4.IX.2005 (VLA) - on a decaying stump in spruce forest. With Mylia verrucosa, Lepidozia reptans and Macrodiplophyllum plicatum.

\section{ACKNOWLEDGEMENTS}

The investigations were partly supported by the grant of the Far-Eastern Branch of the Russian Academy of Sciences (№ 06-III-A-05-153, 06-III-B-06-190, 06-III-Д06-230), International Sakhalin Island Project (ISIP, 20012003), the work of V.A. Bakalin was also supported by RFBR, № 03-04-49304 and the Russian Science Support Foundation of 2005 and 2006. Support of work by J. Harpel was provided in part by the Biological Sciences Directorate (Biotic Surveys and Inventories Program) and the International Program Division of the NSF, DEB9400821, DEB-9505031, and DEB-0071655, Theodore W. Pietsch, principal investigator.

\section{LITERATURE CiteD}

[ALEXANDROVA, A.N.] АЛЕКСАНДРОВА, А.Н. 1982 Плейстоцен Сахалина. - [Pleistocene of Sakhalin] M., Наука [Moscow, Nauka], 220.
AMAKAWA, T. 1959. Family Jungermanniaceae of Japan. I. - J. Hattori Bot. Lab. 21: 248-291.

ATLAS OF SAKHALIN REGION 1994. Part I. Sakhalin Island. 
Topographic map. - Yuzhno-Sakhalinsk, Izd. VTU GSh, 116

BAKALIN, V.A. 2003. A preliminary check-list of the hepatics of Kamchatka Peninsula (Russian Far East). - Arctoa 12: $83-90$.

[BAKALIN, V.A.] БАКАЛИН, В.А. 2004. Печеночники Станового Нагорья (Восточная Сибирь). - [Liverworts of Stanovoye Nagor'e Upplands (East Siberia)] Arctoa 13: 73-83.

[BAKALIN, V.A.] БАКАЛИН, В.А. 2006. Печеночники Кроноцкого заповедника (полуостров Камчатка). - [Liverworts of Kronotsky State Strict Reserve (Kamchatka Peninsula)] Бот. журн. [Bot. Zhurn.] 90: (in print)

[BOGATOV, V.V.] БОГАТОВ, В.В. 2004. Краткий географический очерк острова Сахалин [Brief geographical essay of Sakhalin Island] - Растительный и животный мир Сахалина. Часть 1. - [Flora and fauna of Sakhalin Island. Part 1] Владивосток, Дальнаука [Vladivostok, Dal'nauka]: 8-10.

[DUDA, J.] ДУДА, Й. 1978. К флоре печеночных мхов CCCP. - [To the liverwort flora of USSR] Новости сист. низи. pacm. [Novosti Sist. Nizsh. Rast.] 15: 220-221.

FURUKI, T. \& M. MIZUTANI 1994. Checklist of Japanese Hepaticae and Anthocerotae, 1993. - Proceedings of the Bryological Society of Japan. 6(5): 75-84.

[GAMBARYAN, S.K.] ГАМБАРЯН, С. К. 1992. Антоцеротовые и печеночники Южного Приморья. - [The Hepaticae and Anthocerotae of South Primorye] Владивосток, Дальнаука [Vladivostok, Dal'nauka], 175.

[GAMBARYAN, S.K.] ГАМБАРЯН, С. К. 1993. Состояние изученности печеночных мхов юга Дальнего Востока России. - [The statement of study of liverworts in South Russian Far East] Владивосток, Дальнаука [Vladivostok, Dal'nauka], 23.

HORIKAWA, Y. 1934. Symbolae florae Bryophytae Orientali-Asiae. 2. - Bot. Magaz. Tokyo. 48: 599-609.

KITAGAWA, N. 1963. Hepaticae of Sakhalin. - Acta Phytotax. Geobot. XIX(4-6): 146-152.

KITAGAWA, N. 1966. A revision of the family Lophoziaceae of Japan and its adjacent regions. II. - J. Hattori Bot. Lab. 29: 101-149.

[KONSTANTINOVA, N.A.] КОНСТАНТИНОВА, Н.А 2000. Анализ ареалов печеночников севера Голарктики. - [Distribution patterns of the North Holarctic hepatics] Arctoa 9: 29-94.

KONSTANTINOVA, N.A., A.D. POTEMKIN \& R.N. SCHLJAKOV 1992. Check-list of the Hepaticae and Anthocerotae of the former USSR. - Arctoa 1: 87-127.

KONSTANTINOVA, N.A., V.A. BAKALIN, A.D. POTEMKIN \& M.S. IGNATOV 2002. Hepatic flora of the Upper Bureya River (Russian Far East). - Arctoa 11: 393-398.

[KOROTKEVICH, L.S.] КОРОТКЕВИЧ, Л.C. 1952. Некоторые новые данные к дальневосточной флоре печеночных мхов. - [Some new data on the hepatics flora of Russian Far East] Ботан. мат. omd. cnop. pacm. [Botan. Mat. Otd. Spor. Rast.] 8: 188-196.

LINDBERG, S.O. 1875. Contribution ad floram cryptogamam Asiae boreali-orientalis. - Acta Soc. Sci. Fenn. 10: 223-280.

LINDBERG, S.O. \& H.W. ARNELL 1889. Musci Asiae Borealis. Lebermoose. - Kongl. Svenska Vetenskaps-Akade- miens Handlingar. 23(5): 2-69.

[LOPATIN, V.D.] ЛОПАТИН, В.Д. 1960. Границы растительных поясов в горах острова Сахалин и факторы их обуславливающие. - [Limits of vegetation belts in the mountains of Sakhalin Island and their determining factors] Изв. ВГО [Izv. VGO] 92(4): 349-353.

MIZUTANI, M. 1961 A revision of Japanese Lejeuneaceae. J. Hattori Bot. Lab. 24: 115-302.

PIIPPO, S. 1990. Annotated catalogue of Chinese Hepaticae and Anthocerotae. - J. Hattori Bot. Lab. 68: 1-192.

[PLETNEV, S.P.] ПЛЕТНЕВ, С.П. 2004. Историкогеологическое развитие острова Сахалин. - [Geological development of Sakhalin Island] В кн.: Растительный и животный мир Сахалина. Часть 1. [Flora and fauna of Sakhalin Island. Part 1] Владивосток, Дальнаука [Vladivostok, Dal'nauka]: 11-22.

[POTEMKIN, A.D.] ПОТЕМКИН, А. Д. 2003. Новые и малоизвестные для России печеночники с Камчатки и из Приморского края (Российский Дальний Восток). - [New and little known for Russia hepatics from Kamchatka and Primorsky Territory (Russian Far East)] Arctoa 12: 75-82.

POTEMKIN, A.D. \& S.G. KAZANOVSKY 1993. On the genus Mylia S. Gray (Hepaticae, Jungermanniaceae, Mylioideae). - Arctoa 2: 1-11.

[SAVICZ, L.I.] САВИЧ, Л.И. 1936. Материалы к флоре мхов острова Сахалина. - [Materials to the moss flora of the Sakhalin Island] Вестн. ДВ филиала АН СССР [Vestnik Dalnevost. Fil. Akad. Nauk SSSR] 19: 67-88.

[SCHLJAKOV, R.N.] ШЛЯКОВ, Р.H. 1976. Печеночные мхи Севера ССCР Том. 1. - [Hepatics of the North of USSR. Vol. 1.] Л., Наука [Leningrad, Nauka], 91.

[SCHLJAKOV, R.N.] ШЛЯКОВ, Р.H. 1979. Печеночные мхи Севера СССР Том. 2. - [Hepatics of the North of USSR. Vol. 2.] Л., Наука [Leningrad, Nauka], 191.

[SCHLJAKOV, R.N.] ШЛЯКОВ, Р.Н. 1980. Печеночные мхи Севера СССР Том. 3. - [Hepatics of the North of USSR. Vol. 3.] Л., Наука [Leningrad, Nauka], 188.

[SCHLJAKOV, R.N.] ШЛЯКОВ, Р.H. 1981. Печеночные мхи Севера СССР Том. 4. - [Hepatics of the North of USSR. Vol. 4.] Л., Наука [Leningrad, Nauka], 221.

[SCHLJAKOV, R.N.] ШЛЯКОВ, Р.Н. 1982. Печеночные мхи Севера СССР Том. 5. - [Hepatics of the North of USSR. Vol. 5.] Л., Наука [Leningrad, Nauka], 196.

SCHMIDT, F.B. 1868. Reisen in Amurland und auf der Insel Sachalin, im Auftrage der Kaiserlichen - Russischen Geographischen Gesellschaft ausgefürcht-Mem. Acad. Imp. Sci. St.-Petersburg. 7 Ser. 12(2): 74-75.

[TOLMACHYOV, A.I.] ТОЛМАЧЕВ, А.И. 1955. Геоботаническое районирование острова Сахалина. - [Geobotanical division of Sakhalin Island] $M$.-Л., Изд-во АН СССР [Moscow-Leningrad, Izd-vo AN SSSR], 78.

VANA, J. \& Z. SOLDAN 1985. Some new and phytogeographically interesting bryophytes from Central Siberia. Abstracta Botanica 9(Suppl. 2): 123-144.

YAMADA, K. \& D.-M. CHOE 1997. A checklist of Hepaticae and Anthocerotae of the Korean Peninsula - J. Hattori Bot. Lab. 81: 281-306. 